\title{
O controle das decisões do Presidente da República em relação aos princípios constitu- cionais das relações internacionais
}

\author{
The control of the President's decisions in \\ relation to constitutional principles of interna- \\ tional relations
}

Guilherme Camargo Massaú ${ }^{1}$

Resumo: O texto tem como objetivo analisar qual o
meio juridicamente apto para atacar ato do Chefe de
Estado realizado no exercício da representação do
Estado brasileiro em órgão internacional. Para guiar
a análise, far-se-á o uso do veto do Estado brasileiro
no Conselho de Direitos Humanos da Organização
das Nações Unidas. O veto representou a negativa do
Estado brasileiro em relação à proposta de resolução
do referido conselho em fiscalizar a concretização dos
direitos humanos nos Estados, violando, assim, o prin-
cípio constante no Art. $4^{\circ}$, II, da CF. Para tal análise,

1 Professor da Faculdade de Direito e do Mestrado em Direito da UFPel; Pós-doutor pela PUCRS; Doutor em Direito Público pela Unisinos; Mestre em Ciência Jurídico-Filosóficas pela Universidade de Coimbra; Especialista em Ciências Penais pela PUCRS. Autor dos livros: Metodologia Jurídica. Do início da ciência do direito ao Iluminismo português, ed. Atlas; O princípio republicano do mundo-da-vida do Estado constitucional cosmopolita, ed. Unijuí; O Estado de Direito e as dimensões da res publica, ed. Prismas; Princípios Constitucionais e Relações Internacionais, ed. Livraria do Advogado. E-mail: uassam@gmail.com 
suscitar-se-á se o Chefe de Estado (Presidente) poderá ser responsabilizado ou se o ato é passível de controle de constitucionalidade. Apresentar-se-á, contudo, que nenhuma das hipóteses de solução é aplicável no caso em análise. Por isso, tem-se uma lacuna técnica. Por conseguinte, no último tópico, apontar-se-á uma possível solução à lacuna existente.

Palavras-Chave: Constituição; Princípios; Relações Internacionais; Responsabilidade; Violação.

Abstract: This paper aims to analyze legal ways of countering an act of the Head of State as a representative of Brazil in an international body. To guide the analysis, the veto of the Brazilian State at the Human Rights Council of the United Nations will be focused. This veto represented a refusal of the Brazilian State in relation to a proposed of the Council to monitor the implementation of human rights in associated States, thus violating the principle expressed in Article 4, II, of the Federal Constitution. In order to make such an analysis, it will be discussed whether the Head of State (President) can be held accountable for this refusal or whether the act is subject to constitutional control. It will be stated, however, that none of solution prospects are applicable in this case. Therefore, there occurs a technical gap. Finally, in the last topic, a possible solution to the existing gap is pointed out.

Keywords: Constitution; Principles; International Relations; Responsibility; Breach.

Sumário: 1 Introdução; 2 Estado de Direito e a abrangência da responsabilidade jurídica; 3 Função do Art. $4^{\circ}$ da Constituição Federal; 4 Competência do Chefe de Estado; 5 Responsabilidade Jurídica do Chefe de Estado; 5.1 Suporte fático constitucional; 5.2 Suporte 
fático da Lei n. 1.079/1950; 5.2.1 Ausência de regulamentação; 6 (Im)Possibilidade de utilização de ações constitucionais contra ato inconstitucional nas relações internacionais; 6.1 Ação Direta de Inconstitucionalidade; 6.2 Arguição de Descumprimento de Preceito Fundamental; 7 Proposta de solução; 8 Conclusão; Referências bibliográficas.

\section{Introdução}

Este texto objetiva verificar a existência e os eventuais meios de atacar ato político ou de governo inconstitucional do Chefe de Estado ou de seus acreditados em órgão internacional, do qual o Estado brasileiro faça parte. Optou-se por essa análise pelo fato de o Estado brasileiro ter vetado proposta de resolução (A/HRC/34/L.3) no Conselho de Direitos Humanos da Organização das Nações Unidas, em 23 de março de $2017^{2}$. Tal proposta de Resolução foi submetida ao Conselho de Direitos Humanos com o intuito de renovar o mandato de experts da Organização das Nações Unidas incumbidos do monitoramento do impacto das políticas fiscais sobre os direitos humanos nos Estados vinculados à Organização.

Parte-se da hipótese de que o veto à proposta de resolução do Conselho de Direitos Humanos por parte do Estado brasileiro representou uma violação à prescrição do Art. $4^{\circ}$, II, da $\mathrm{CF}^{3}$. Dessa forma, está-se diante de um ato inconstitu-

2 Trata-se da Resolução A/HRC/34/L.3 (Mandate of the Independent Expert on the effects of foreign debt and other related international financial obligations of States) no $56^{\text {th }}$ Meeting, $34^{\text {th }}$ Regular Session Human Rights Council. No endereço na internet (webtv.un.org) encontra-se o vídeo do pronunciamento da acreditada Márcia Canário de Oliveira sobre a posição do Estado brasileiro em relação à Resolução supramencionada.

3 MASSAÚ, Guilherme. A função dos princípios fundamentais do Art. $4^{\circ}$ da Constituição Federal de 1988. Monografia de Estágio Pós-Doutoral com o Prof. Dr. 
cional realizado no âmbito internacional, o qual esgota-se em si e representa - no tempo - uma inconstitucionalidade, justamente pelo fato de o ato político ou de governo ter ultrapassado os limites fundamentadores do princípio da prevalência dos direitos humanos. Supõe-se que, assim como se deu a violação do princípio da prevalência dos direitos humanos, outras violações possam ocorrer com os demais princípios elencados nos incisos do Art. $4^{\circ}$ da CF.

Diante disso, resta analisar se o Estado de Direito constitucional brasileiro suporta ou não a violação de tais princípios constitucionais, que se encontram, topograficamente, no início da Constituição Federal e que atribuem a ela identidade normativa interna e externamente. Para a realização da análise, esboçar-se-á a estrutura do Estado de Direito e se situar-se-á a responsabilidade jurídica do Chefe de Estado. Após, pontuar-se-á a função do Art. $4^{\circ}$ da CF no ordenamento brasileiro. Por conseguinte, é preciso delimitar a competência constitucional do Chefe de Estado. Esses elementos permitirão que se aborde a responsabilidade do Chefe de Estado quando de sua atuação no âmbito internacional no condizente à participação em órgão internacional. Delineadas as possibilidades de responsabilização ou não, enfrentar-se-á a possibilidade de utilização de remédio constitucional contra o citado ato inconstitucional.

Ao cumprir essas etapas, analisando-se os possíveis posicionamentos, ter-se-á, no último tópico, resposta, dentre outras possivelmente existentes, ao problema suscitado quando da aplicação dos princípios constitucionais que regem as relações internacionais. Em termos de fundamento,

Ingo Wolfgang Sarlet na Pontifícia Universidade Católica do Rio Grande do Sul, 2017. Esse estudo serve de base pré-compreensiva para se entender a inconstitucionalidade do referido veto do Estado brasileiro no âmbito do Conselho de Direitos Humanos. 
a análise aqui a ser efetuada condiz com a força vinculativa das normas constitucionais.

Trata-se de pesquisa realizada no âmbito das ciências jurídicas, inserida na grande área das ciências sociais aplicadas. Dessa forma, empregou-se o método hipotético-dedutivo, na medida em que se partiu do geral ao particular em relação à possibilidade hipotética de violação de princípio constitucional por parte do chefe de Estado e ligação com a possível existência de sanção. Empregou-se a pesquisa bibliográfica, justamente por se tratar de uma análise constitucional-normativa. Dessa forma, utilizou-se artigos de periódicos e livros técnicos. Por ser um tema pouco explorado, não se encontrou jurisprudência

\section{Estado de Direito e a abrangência da respon- sabilidade jurídica}

O Estado de Direito consiste em limitar o poder estatal por meio da ordem jurídica. Ele surge, em suma, para garantir determinada esfera de liberdade aos cidadãos e os direitos fundamentais. Para que isso ocorra, pautou-se no sistema constitucional, limite das prerrogativas do Estado e da liberdade do povo ${ }^{4}$. Conjuntamente, têm-se diversos princípios e instituições que perfazem o sistema do Estado de Direito constitucional, tais como: princípio da legalidade; princípio da superioridade hierárquica da constituição; divisão funcional entre os Poderes Executivo, Legislativo e Judiciário; a existência de direitos fundamentais, dentre outros.

Tais características estão traduzidas na formalidade legal, que consiste na vinculação do Estado às regras gerais

4 ZIPPELIUS, 1994, p. 287, 288. 
e abstratas produzidas por meio de processo específico e publicizadas. O texto constitucional impõe o princípio da legalidade para balizar a administração pública, instituindo a organização e a competência administrativas. Soma-se a isso a materialidade que diz respeito às garantias de justiça material, à segurança da liberdade e ao fundamento do Estado social. Dessa forma, o legislador encontra-se vinculado aos direitos fundamentais e aos direitos humanos dentre outros desdobramentos. Nesse sentido, surge a dissonância entre legitimidade e legalidade ${ }^{5}$.

Não se adentrará na explicação do Estado de Direito constitucional, uma vez que o importante é ressaltar que todas as atividades do Estado devem estar legitimadas e de acordo com o texto constitucional, inclusive as políticas de cunho internacional. Destarte, mesmo considerando atividade política do Estado brasileiro, essa deve encontrar-se impreterivelmente circunscrita aos limites normativos da Constituição. É o controle do poder político por meio dos parâmetros constitucionais ${ }^{6}$. Nota-se que a garantia e a afirmação da identidade política, reconhecimento e garantia dos direitos fundamentais e a imposição de fins, programas e tarefas estatais são características incontornáveis do sistema constitucional $^{7}$. Com isso, justifica-se o Art. $5^{\circ}, \mathrm{XXXV}$, da CF, que possibilita ao Poder Judiciário realizar o controle de constitucionalidade. Destaca-se que o Legislador Constituinte Originário previu uma série de princípios reitores das relações internacionais do Estado brasileiro, o que significa que o mesmo estabeleceu linhas gerais imperativas para serem seguidas pelas políticas de Estado dos governos brasileiros.

\footnotetext{
5 KRIELE, 1990, p. 104.

6 SARLET, 2014, p. 87.

7 SARLET, 2014, p. 86
} 
Salienta-se que a preocupação constitucional que acarreta na responsabilidade ${ }^{8}$ política desempenha função reguladora e normativa. Ela converte o poder político de um imperium de força ilimitada em autoridade controlável e limitada pelo direito. Tem-se no texto normativo constitucional os fundamentos e os seus limites de atuação do poder político, sob pena da perda do poder ${ }^{9}$. As limitações jurídicas são constitucionalmente essenciais em relação à política e se referem às funções e às regras estabelecidas com o objetivo de organizar, limitar e controlar o poder político. É necessário o reconhecimento de que, ao estabelecer as condições de exercício do poder político, a constituição definiu limites ao mesmo ${ }^{10}$, que por sua vez são também, controlados por ações e remédios constitucionais, acionados quando da violação constitucional por parte dos poderes constituídos. Deles resultam responsabilizações de agentes públicos e/ou declaração de nulidade de atos normativos.

\section{Função do Art. $4^{\circ}$ da Constituição Federal ${ }^{11}$}

O Art. $4^{\circ}$ da CF é pouco explorado pela doutrina constitucional pátria. Por isso, tem-se a relevância da análise das consequências da incidência normativa de tal artigo. É preciso reconhecer que são princípios constitucionais os quais

8 BROSSARD, 1992, p. 3-5. Destaca-se que a responsabilidade político-constitucional não está vinculada, necessariamente, à culpa, ao dolo ou à negligência. Dessa forma, o Presidente pode não ser responsabilizado disciplinar ou criminalmente por decisões erradas, comportamentos ilegais dos órgãos ou falhas nos serviços, mas poderá ser responsabilizado politicamente por tais disfunções. CANOTILHO, 2002, p. 549.

9 LOMBA, 2008, p. 11, 12-13 e 58.

10 LOMBA, 2008, p. 22-23; SARLET, 2014, p. 86.

11 Em relação à função do Art. $4^{\circ}$ da CF, vide estudo mais detalhado: MASSAÚ, 2017. 
possuem força normativa. Trata-se de texto normativo norteador das relações internacionais na Constituição brasileira. Junto aos três primeiros artigos, o Art. $4^{\circ}$ da CF compõe as diretrizes normativas específicas do Estado, determinando-lhe o modo de ser e agir. Conjuntamente com os princípios estruturantes, os princípios das relações internacionais contribuem para a obtenção de postulados fundamentais e dos objetivos constitucionais. Têm como função e finalidade orientar a unidade jurídica da Constituição e guiar o interprete dos órgãos dos Poderes Legislativo, Judiciário e Executivo nas suas ações constitucionais, aumentando a eficácia do sistema ${ }^{12}$.

É preciso destacar que as normas constitucionais possuem determinado grau de eficácia. Sem isso, elas não teriam um mínimo grau de exigibilidade. Para situar a eficácia dos princípios constitucionais das relações internacionais, utilizar-se-á a seguinte classificação: normas constitucionais de alta densidade normativa e de baixa densidade normativa ${ }^{13}$. As primeiras possuem suficiente carga de normatividade para gerar seus efeitos fundamentais; por conseguinte, não dependem de ulterior restringibilidade e intervenção do legislador, enquanto que as segundas necessitam de complementação de normas infraconstitucionais para gerarem seus efeitos, embora irradiem mínimo grau de normatividade, característico de todas as normas constitucionais ${ }^{14}$. Diante dessa classificação, serão incluídas entre as primeiras as normas, aquelas que se encontram no Art. $4^{\circ}$, I, II, III, IV, V, VI, VII, VIII, IX e X, da CF. Tratam-se de "normas-quadro", na medida em que suas densidades são intensas e amplas ${ }^{15}$.

12 BULOS, 2009, p. 409; no mesmo sentido: AGRA, 2007, p. 84.

13 SARLET, 2015, p. 258-259.

14 SARLET, 2014, p. 186; SARLET, 2015, p. 260-261.

15 Somada a essa classificação, parece ser possível invocar a variante da dis- 
Deixa-se assinalado que todas as proposições jurídicas, no caso, as constitucionais, são destinadas a serem aplicadas a eventos fáticos - trata-se da força normativa da Constituição. Portanto, os princípios situados no Art. $4^{\circ}$ da CF são princípios materiais, que carregam valores substanciais à ordem jurídica. Contudo, em termos formais, não há a conexão explícita e imediata entre o suporte fático e a consequência jurídica; mesmo assim, eles conduzem a regulações ${ }^{16}$ e a comportamentos - no caso, das relações internacionais do Estados brasileiro. Nesse sentido, os atos referentes às relações internacionais são limitados, conformados e dirigidos positivamente por esses princípios jurídico-políticos constitucionais ${ }^{17}$. Àqueles atos que violarem os parâmetros de compreensão desses princípios devem ser considerados inconstitucionais ${ }^{18}$.

\section{Competência do Chefe de Estado}

Conforme a regra de competência ${ }^{19}$ constitucional, cabe ao Executivo da União conduzir as relações internacionais do Estado brasileiro e, por conseguinte, interpretar ${ }^{20}$ e con-

sociação em alternativas inclusivas (de Ávila). Ao se examinar formalmente os dispositivos do Art. $4^{\circ}$ da CF citados, é possível determiná-los como regras, porque condicionam a validade dos atos das relações internacionais à observância dos princípios, pois estes estabelecem a devida observação dos valores ali descritos. ÁVILA, 2012, p. 75.

16 LARENZ, 2001, p. 33.

17 CANOTILHO, 1994, p. 285; SILVA, 1999, p. 97.

18 Aqui reside o problema dessa análise, como se verá nos últimos tópicos do texto. No que se refere a ato político ou de governo do Estado brasileiro, quando participa de órgão internacional, não existe remédio constitucional que possa atacar a inconstitucionalidade ou não se pode responsabilizar o Chefe de Estado por sua opção política, violadora de norma constitucional.

19 ÁVILA, 2012, p. 1153; GUASTINI, 2010, p. 163.

20 Não se pode ignorar que, como será tratado em outro texto, que, ao interpretar a Constituição, o intérprete deve ter em conta o princípio da concor- 
cretizar os princípios constantes do Art. $4^{\circ}$ da CF. A natureza aberta de tais princípios requer, por parte do intérprete, espaço de discricionariedade na condução das relações internacionais, para que sejam determinadas as decisões políticas na seara internacional. Dessa forma, diante da amplitude dos princípios, o Poder Executivo (Art. 76, caput, da CF) ${ }^{21}$, por meio do Presidente da República (Chefe de Estado) pode escolher a sua política dentro dos limites interpretativo-textuais dos princípios ${ }^{22}$, levando em consideração as circunstâncias nacionais e internacionais ${ }^{23}$. Destaca-se que os princípios fundamentais das relações internacionais se constituem em guia dos dirigentes eleitos assim como dos agentes diplomáticos no que se refere à postura do Estado brasileiro no plano internacional ${ }^{24}$. Além disso, o caráter de representação política do Chefe de Estado, não o torna irresponsável; pelo contrário, o obriga a ser transparente na justificava e fundamentação de suas decisões ${ }^{25}$.

Devido à regra de competência ${ }^{26}$ privativa do Presidente da República - na função de Chefe de Estado - (Art. 84, VII e VIII, da CF) - de manter relações com Estados estrangeiros, acreditar seus representantes diplomáticos (VII) e celebrar tratados, convenções e atos internacionais (treaty-making power) - sujeitos ao referendo do Congresso Nacional (VIII),

dância prática para não infringir o texto constitucional. HESSE, 1993, p. 27-28; SARLET, 2014, p. 223-224.

21 TAVARES, 1996, p. 166.

22 UZIEL, MORAES, RICHE, 2017, p. 104-105.

23 A amplitude desses princípios é propícia para que o Poder Executivo utilize sua discricionariedade com maior amplitude e liberdade, já que o mesmo necessita de amplitude para poder sopesar as imprevisibilidades decorrentes do cenário das relações internacionais que é instável. Vide: UZIEL, MORAES, RICHE, 2017, p. 104-105.

24 ALMEIDA, 1989, p. 56.

25 LOMBA, 2008, p. 78.

26 CANOTILHO, 2002, p. 1153 
não cabe ao Poder Legislativo tratar tais princípios como normas programáticas nem os regulamentar ou restringi-los. Caberá, quando lhe for de competência, não referendar tratados, convenções e atos internacionais contrários aos princípios constitucionais, assim como ao Poder Judiciário cabe a defesa da Constituição e das normas em vigor no Estado brasileiro. Com isso, tratados, convenções e atos internacionais referendados, mas que sejam inconstitucionais, devem ser declarados como tais e excluídos, quando internalizados, do sistema jurídico brasileiro ${ }^{27}$ pelo Poder Judiciário.

A função do Art. $4^{\circ}$ da CF, dessa forma, é restringir e orientar a atuação do Chefe de Estado ${ }^{28}$ e seus acreditados nas relações internacionais, os quais têm obrigatoriedade de escolher políticas externas que se encaixem no suporte fático dos princípios do referido artigo. Nesse sentido, a Constituição brasileira garante a manutenção da identidade do Estado perante a esfera internacional, além de estar alinhada aos preceitos axiológicos da Organização das Nações Unidas. Todavia, essa restrição e orientação não impede o Poder Executivo de pôr em prática suas opções políticas. Ele poderá diante do caso concreto decidir e agir politico-juridicamente, a fim de preencher discricionariamente o espaço de compreensão material dos princípios, conforme parâmetros estabelecidos pela própria Organizações das Nações Unidas ${ }^{29}$, regras contidas em tratados, pactos, atos e costumes internacionais e subprincípios, e.g., princípio da não indiferença ${ }^{30}$, derivados dos princípios elencados na Constituição brasileira.

27 Tal tema será tratado em artigo específico, pois suscita outros desdobramentos que fogem do objetivo dessa análise.

28 GALINDO, 2013, p. 1239.

29 UZIEL, MORAES, RICHE, 2017, p. 108.

30 UZIEL, MORAES, RICHE, 2017, p. 109. 


\section{Responsabilidade Jurídica do Chefe de Estado}

Esse tópico tem como único objetivo situar, somente, a responsabilidade do Chefe de Estado (Presidente da República) em relação a ato ${ }^{31}$ que viola princípio constitucional das relações internacionais (Art. $4^{\circ}$ da CF). Dessa forma, é necessário tratar do Art. 85, caput e VII, da CF e da Lei n. 1.079/1950. Com isso, destaca-se que se tratará de crimes de responsabilidade, que estão relacionados às infrações político-administrativas definidas por lei ${ }^{32}$. Não se analisará outra tipificação ou as regras processuais referentes aos crimes de responsabilidade do Presidente ${ }^{33}$.

31 Trata-se tal ato como político ou de governo por ter as seguintes características, mesmo sendo realizado na ordem internacional: 1) todas as ações do Presidente estão limitadas ao texto constitucional (é o que legitima); 2) é uma declaração que produz efeitos jurídicos (no caso internacional), o que se encaixa como fato jurídico; 3) encaixa-se como declaração de vontade; por conseguinte, trata-se de ato discricionário; 4) tem ampla margem de discricionariedade, inobstante serem controláveis pelo Poder Judiciário (Art. 5, XXXV, da CF). MELLO, 2001, p. 337, 339 e 340, 342-343; SILVA, 2010, p. 496.

32 STRECK, OLIVEIRA, BAHIA, 2013, p. 1286. Para isso, o sujeito politicamente responsável possui "liberdade" e "discricionariedade" de decisão. LOMBA, 2008, p. 111.

33 Nota-se que, embora a responsabilidade do Presidente da República, referente ao Art. 85 da CF, seja denominada de política, tem-se no texto constitucional a tipicidade geral que é definida pela Lei n. 1.079/1950. Dessa forma, fica a questão, mesmo que se viole o texto legal e constitucional expressamente, o Presidente da República poderá não sofrer o impeachment? A questão já está respondida na prática, já que depende de decisão política de admissibilidade que ocorre na Câmara dos Deputados e no Senado Federal. Em última instância depende da representatividade do Chefe do Executivo no Congresso Nacional. Contudo, um Estado de Direito com sistema jurídico deveria suportar violações expressas a textos normativos (inclusive o constitucional) sob o argumento da necessidade de anuência política? Não pois, é um contrassenso, na medida que o Servidor público realiza, clara e confessadamente, tipo considerado constitucionalmente ilegal e, mesmo assim, politicamente se mantem incólume. Logo, está-se diante de uma violação constitucional e legal em que o sistema jurídico tolera por opção política. 


\subsection{Suporte fático constitucional}

Em termos textuais, o artigo constitucional desaguaria na interpretação de que atos que atentem contra a Constituição e ao cumprimento das leis resultaria na responsabilidade do Presidente da República. É preciso destacar que o Art. 85, caput, da CF traz dois suportes fáticos: São crimes de responsabilidade os atos do Presidente da República que atentem 1) contra a Constituição Federal e, especialmente 2) contra...VII - o cumprimento das leis e das decisões judiciais.

Como se pode compreender, atentar contra a CF é crime de responsabilidade, conforme o texto normativo constitucional $^{34}$. Dessa forma, violar princípio constitucional atenta contra a Constituição, em uma interpretação ampliada; em uma perspectiva mais restrita ${ }^{35}$, o ato que atenta contra à $\mathrm{CF}$ deve ser aquele que ponha em risco a existência da Magna Carta.

Dessa forma, acredita-se que, para manter (natureza política) o sistema do juízo de admissibilidade e de julgamento políticos, é preciso torna-lo genérico - como é o caso do Art. 2 seção IV da Constituição norte-americana - e condicionados às ações essencialmente políticas os fatos típicos previstos no Art. 85 da CF e revogar qualquer lei infraconstitucional que o discipline ou especifique as condutas. Contudo, seria necessário manter as regras infraconstitucionais para o processamento do Presidente. As figuras típicas que se encontram elencadas na Constituição e especificadas na Lei n. 1.079/1950 compõem mais "crimes constitucionais" do que crimes de responsabilidade política, devido à sua natureza. Para se ter uma ideia de aspectos históricos do impeachment, vide: CRETELLA JÚNIOR, 2011, p. 502; segundo Cretella Júnior, no artigo citado, o impeachment no direito brasileiro não tem qualquer caráter algum jurisdicional, sendo em sua essência administrativo (p. 505). Também: FIGUEIREDO, 1965, p. $32-36$ e 37. Segue-se a posição de que o Impeachment brasileiro não se equipara ao americano, inglês, alemão ou outros. PONTES DE MIRANDA, 1959, p. 57; também: BROSSARD, 1992, p. $5-6,35,52$.

34 Vide: BROSSARD, 1992. p. 54-55.

35 Considera-se a interpretação restrita mais correta, vide os argumentos de BROSSARD, 1992, p. 54-56. 
Contudo, soma-se à primeira hipótese o inciso VII do Art. 85 da CF, que trata do dever do Presidente do cumprimento das leis e das decisões judiciais. Por consequência lógica, se o não cumprimento das leis (infraconstitucionais) gera responsabilidade, com maior propriedade, o não cumprimento de mandamento normativo constitucional também deve acarretar responsabilidade. Caso contrário, normas hierarquicamente inferiores teriam um grau de proteção e responsabilização maior do que as hierarquicamente superiores.

No entanto, conforme o parágrafo único do citado artigo, lei especial deve definir ${ }^{36}$ os suportes fáticos elencados no Art. 85 da CF. Destaca-se que a lei especial que definir os suportes fáticos referentes aos incisos do Art. 85 da CF deve estar em consonância com e especificar o texto constitucional.

\subsection{Suporte fático da Lei n. 1.079/1950}

A Lei n. 1.079/1950 foi recepcionada pela CF de 1988, tanto que foi empregada em dois processos de responsabilidade de Presidentes - o do Presidente Fernando Collor de Melo (1989) e da Presidente Dilma Rousseff (2017). Dessa forma, o Supremo Tribunal Federal acabou por reconhecer sua recepção, aqui, principalmente, no que diz respeito aos preceitos jurídicos utilizados nos dois processos de impeachment. Com isso, o texto da Lei n. 1.079/1950, criada sob a vigência da Constituição de 1946, disciplina os crimes de responsabilidade e regula o respectivo processo de julga-

36 Cabe à União definir os crimes de responsabilidade, decisão do Supremo Tribunal Federal constante da Súmula Vinculante 46. A Lei n. 1079/1950 foi recepcionada, em grande parte, pela CF/1988. MS 21.623, rel. min. Carlos Velloso, j. 17-12-1992, P, DJ de 28-5-1993. BRASIL. Supremo Tribunal Federal, 2016, p. 793-794. Sobre a não recepção do Art. 11 da Lei n. 1.079/50, vide: BARROSO, 2011, p. 629. 
mento do Chefe de Estado, conforme designa o parágrafo único do Art. 85 da CF; tal lei compõe o denominado bloco de constitucionalidade, por versar matéria expressamente constitucional ${ }^{37}$.

O que se destaca é o caput do Art. $4^{\circ}$ e o Art. $5^{\circ}$, item 11, da Lei n. 1.079/1950. O caput do Art. $4^{\circ}$ é semelhante ao caput do Art. 85 da CF: São crimes de responsabilidade os atos do Presidente da República que atentarem contra a Constituição Federal, e, especialmente, contra... A semelhança entre os dois textos normativos se encerra na vírgula existente no Art. $4^{\circ}$, enclausurando o e (...Constituição Federal, e, especialmente). $\mathrm{O}$ $e$ estando entre vírgulas remete à compreensão de que os atos que atentam contra a república são, especialmente, os constantes dos incisos do Art. $4^{\circ}$ da Lei n. 1.079/1950. Isso se diferencia da hipótese estabelecida pela redação do caput do Art. 85 da $\mathrm{CF}^{38}$.

No caso em voga, reconhecida e admitida tal diferença a única solução para a antinomia é a não recepção constitucional da vírgula que antecede o $e$. Por conseguinte, deve-se ler o caput do Art. $4^{\circ}$ tal qual o caput do Art. 85 da CF, isso pelo fato de se estar diante de um conflito de normas com hierarquias diferentes, prevalecendo o texto normativo constitucional. Entretanto, tal prevalência é questionável na medida em que o parágrafo único do Art. 85 da $\mathrm{CF}$ remete à lei infraconstitucional a regulamentação do Art. 85 da CF. Com efeito, o dispositivo constitucional necessita de regula-

37 SARLET, 2014, p. 91.

38 José Afonso da Silva entende que atentar contra a constituição configura crime de responsabilidade, mas a lei complementadora manteve genericamente (como visto acima) a expressão e não a regulamentou. Contudo, o mesmo autor admite que é difícil estabelecer uma configuração do que seja atentar contra a Constituição, porém argumenta no mesmo sentido do acima exposto, ou seja, atos que ponham em risco a existência da Magna Carta. SILVA, 2010, p. 496-497. 
mentação para ser aplicado. Nesse caso, tem-se a prevalência do texto normativo infraconstitucional, desde que não seja inconstitucional, o que não é o caso, segundo o Supremo Tribunal Federal.

Como a análise do texto refere-se aos princípios que incidem nas relações internacionais do Estado brasileiro cabe perscrutar se violá-los acarreta a incidência do suporte fático do Art. 5, item 11, da Lei n. 1.079/1950. O item 11 tipifica como crime de responsabilidade contra a existência política da União violar tratados legitimamente feitos com nações estrangeiras; com essa redação, encontra-se afastada a incidência do suporte fático do item 11 do Art. $5^{\circ}$, pois o que está sendo violado é princípio constitucional e não, necessariamente, norma de direito internacional ou se trata de constituição de ato que ponha em risco a existência da União ${ }^{39}$.

A responsabilidade do Chefe de Estado em violar princípio constitucional das relações internacionais em órgão internacional fica afastada; além disso, ato inconstitucional é indiferente no âmbito internacional pelo fato da inexigibilidade do órgão internacional que o Estado siga, em termos internacionais, sua própria Constituição. Ainda, como se trata de um crime de responsabilidade, a interpretação do dispositivo deve ser restrita ao conceito de tratado e de nação, o que não é o caso do ato de desrespeitar um dos princípios do Art. $4^{\circ}$ da CF em face de órgão colegiado da Organização das Nações Unidas.

\subsubsection{Ausência de regulamentação}

Cabe destacar que a Lei n. 1.079/1950 na sua previsão legal não regulamenta a primeira parte do inciso VII do Art.

39 SILVA, 2010, p. 497. 
85 da CF. No seu Art. $4^{\circ}$, VIII, consta a previsão do cumprimento das decisões judiciárias, mas dentre os seus incisos não se verifica o suporte fático do cumprimento das leis, como está previsto constitucionalmente ${ }^{40}$. O Art. 12 da Lei n. 1.079/1950 prevê os fatos típicos referentes aos atos que vão de encontro às decisões judiciais. Por conseguinte, na ausência de previsão específica, deve-se entender que o não cumprimento das leis (e da Constituição) é fato típico, passível de servir como denúncia de crime de responsabilidade do Presidente da República, ao violar princípio constitucional das relações internacionais ${ }^{41}$. Outra possibilidade que surge é considerar uma omissão infraconstitucional - passível de uma Ação Direta de Inconstitucionalidade por Omissão - pela ausência de regulamentação da primeira parte do inciso VII do Art. 85 da CF. Essa última opção é a mais plausível justamente pelo parágrafo único do Art. 85 da CF. Trata-se de uma omissão

40 Destaca-se que a Lei n. 1.079/1950 regulamentava o Art. 89 da Constituição brasileira de 1946, conforme o parágrafo único do citado artigo. Dentre as hipóteses estabelecidas com crime de responsabilidade pela Constituição de 1946 não constava o cumprimento das leis, mas somente, no inciso VIII, tal qual o Art. $4^{\circ}$, VIII da Lei de 1950, o cumprimento das decisões judiciárias. Por conseguinte, à época não existia omissão constitucional. Com a recepção da Lei n. 1.079/1950 pela Constituição de 1988, acabou-se por constituir, supervenientemente, uma omissão de caráter constitucional, que é a falta de regulamentação para a parte do cumprimento das leis, do Art. 85, VII, da CF. CAMPANHOLE, CAMPANHOLE, 1986, p. 250.

41 José Afonso da Silva nota a ausência de regulamentação no que diz respeito ao cumprimento das leis, porém pensa ser exagerado estabelecer tal fato típico. SILVA, 2010, p. 498-499. Exagerado ou não, o texto constitucional prevê a hipótese; logo, cabe ao legislador infraconstitucional regulamentá-la. Como se notará no texto, existem atos do Presidente da República que não são tangíveis pelo controle de constitucionalidade nem por remédios constitucionais. Se essa hipótese existe e ignora-se qualquer responsabilização ou nulidade de ato notoriamente inconstitucional, então é preciso admitir que em determinados espaços constitucionais o Presidente da República (no caso Chefe de Estado) pode agir à margem do texto constitucional e, por isso, encontra-se acima do mesmo? Defende-se que não. 
inconstitucional superveniente à Constituição de $1988^{42}$.

Dessa forma, a tipificação constitucional constante do Art. 85 da CF é de reserva constitucional, sendo insuscetível de extensão discricionária pelo legislador infraconstitucional $^{43}$. É de caráter classificatório, tendo como objetivo delimitar as definições dos crimes pela lei especial, como indica o parágrafo único ${ }^{44}$. Sendo assim, na ausência da regulamentação da primeira parte do inciso VII do Art. 85 da $\mathrm{CF}$, não se deve cogitar em crime de responsabilidade o não cumprimento das leis. Portanto, perante o descumprimento de regra ou princípio constitucional do Presidente da República (Chefe de Estado) resta verificar se é possível anular ou declarar nulo ato violador de comando normativo constitucional.

\section{6 (Im)Possibilidade de utilização de ações cons- titucionais contra ato inconstitucional nas relações internacionais}

Verificada a hipótese de não responsabilização do Chefe de Estado (Presidente da República), resta saber se o ato/fato inconstitucional, objeto de análise, pode ser atacado por remédio constitucional. A primeira questão que se estabelece como determinada (no caso em voga) é de se estar diante de uma ação e não de uma omissão. Por conseguinte, não se trata de Ação Declaratória de Inconstitucionalidade por Omissão.

42 DIMOULIS, LUNARDI, 2011, p. 94.

43 BARROSO, 2011, p. 628-629.

44 STRECK, OLIVEIRA, BAHIA, 2013, p. 1287. 


\subsection{Ação Direta de Inconstitucionalidade}

A Ação Direta de Inconstitucionalidade (genérica) tem como objetivo excluir do sistema jurídico lei ou ato normativo inconstitucional (Art. 102, I, a, da CF), que comprometem o sistema constitucional por sua qualidade de inconstitucionalidade ${ }^{45}$. Dessa forma, o objeto da ação é a validade da lei ou ato normativo federal ou estadual em tese, ou seja, independente da existência de caso concreto em face da Constituição. Dessa forma, o controle concentrado tem como objeto norma dotada de abstração, generalidade e impessoalidade. Por conseguinte, os atos administrativos que possuem objeto determinado e destinatários não são passíveis de ação direta de inconstitucionalidade, justamente pela ausência de abstração ${ }^{46}$.

No caso em análise, se trata de ato político ou de governo concreto ${ }^{47}$ que se exauriu com o agir do Chefe de Estado ou do acreditado brasileiro ao declarar posição do Estado brasileiro no Conselho de Direitos Humanos. Contudo, tal concretude e exaurimento consiste na impossibilidade de anulação da decisão na mesma Sessão (56 $6^{\text {th }}$ Meeting, $34^{\text {th }}$ Regular Session) e sobre o mesmo objeto. Soma-se a isso a competência privativa do Chefe de Estado em representar o Estado brasileiro no plano internacional e a impossibilidade jurisdicional do Supremo Tribunal Federal de impor sua decisão ao órgão internacional. Por esses critérios, é inadmissível que tal inconstitucionalidade seja atacada pela ação direita de inconstitucionalidade.

45 DIMOULIS, LUNARDI, 2011, p. 102.

46 SIQUEIRA JR., 2011, p. 204 e 231-232; DIMOULIS, LUNARDI, 2011, p. 108; MARINONI, 2014, p. 1065-1066.

47 DIMOULIS, LUNARDI, 2011, p. 112; MARINONI, 2014, p. 1070. 


\subsection{Arguição de Descumprimento de Preceito Fundamental}

A Arguição de Descumprimento de Preceito Fundamental (Art. 102, $\$ 1^{\circ}$, da CF) tem como finalidade defender a integridade da Constituição, no condizente aos preceitos fundamentais, perante o Supremo Tribunal Federal. Nesse sentido, objetiva evitar ou reparar lesões aos princípios, direito e garantias constitucionais, inclusive diante de caso concreto, de forma incidental ${ }^{48}$. As hipóteses cabíveis de sua utilização são: 1) evitar lesão a preceito fundamental (Art. $1^{\circ}$, caput, da Lei n. 9.882/99); 2) reparar lesão a preceito fundamental (Art. $1^{\circ}$, caput, da Lei n. 9.882/99); 3) controvérsia relevante sobre lei ou ato normativo oriundos do Poder Público federal, estadual e municipal (Art. $1^{\circ}$, parágrafo único, I, da Lei n. 9.882/99). Há que se levar em consideração, conforme a lei que regulamenta essa arguição, quatro dimensões: 1) atos do Poder Público; 2) leis ou atos normativos municipais; 3) leis ou atos normativos anteriores à Constituição; 4) atos inacabados do Poder Público ${ }^{49}$.

Em relação à analise do caso em concreto, é preciso destacar que se trata de um ato político ou de governo emanado do Poder Executivo da União que declara e vincula o Estado brasileiro à uma decisão em âmbito internacional e, simultaneamente, descumpre preceito fundamental constitucional. No caso em análise, ocorreu uma violação, um descumprimento a mandamento constitucional expresso e desrespeito à finalidade constitucional ${ }^{50}$.

48 MARINONI, 2014, p. 1269-1270.

49 SIQUEIRA JR., 2011, p. 319-320; DIMOULIS, LUNARDI, 2011, p. 161-162.

50 DIMOULIS, LUNARDI, 2011, p. 170-171; MARINONI, 2014, p. 1278. 
Resta saber se os princípios do Art. $4^{\circ}$ da CF se encaixam no conceito de preceito fundamental. Destarte, preceitos fundamentais são aqueles que servem de alicerce do sistema constitucional. Além disso, estabelecem comandos essenciais expostos pelo Legislador Constituinte. Assim, qualquer ação ou omissão que os contrariem substancialmente dá azo ao ingresso da Arguição de Preceito Fundamental no Supremo Tribunal Federal ${ }^{51}$.

Em face disso, as características do Art. $4^{\circ}$ da CF encaixam-se com a concepção de preceito fundamental. Em termos topográficos, os princípios encontram-se no início do texto constitucional. Eles apresentam o caráter de essencialidade, já que sustentam a ação do Estado brasileiro quanto a relações internacionais. Eles também apresentam conteúdo oriundo do direito internacional, ou seja, são opções pontuais do Legislador Constituinte. Por conseguinte, pode-se dizer que tais princípios constituem preceitos fundamentais. Se violados por ato do Poder Público, podem servir de base para a Arguição.

A questão é saber se o ato do veto do Estado brasileiro no Conselho de Direitos Humanos que violou o Art. $4^{\circ}$, II, da CF pode ser atacado pela ação de Arguição. Tal veto é ato do Poder Público e atinge preceito fundamental, porém, por sua natureza, é impossível reparar lesão. Isso porque o voto no Conselho de Direitos Humanos se exaure no mesmo momento em que é emanado, pois se dá à vinculação do Estado brasileiro a posição que significa o veto dentro do contexto decisão de causa e consequência. Além disso, ine-

51 SIQUEIRA JR., 2011, p. 317; DIMOULIS, LUNARDI, 2011, p. 174. Defende-se que essa concepção de preceito fundamental esteja de acordo com os seguintes julgados do Supremo Tribunal Federal: ADPF 33 MC, rel. min. Gilmar Mendes, j. 6-6-2013, P, DJ de 6-8-2004; ADPF 101, rel. min. Cármen Lúcia, j. 24-6-2009, P, DJE de 4-6-2012. BRASIL. Supremo Tribunal Federal, 2016, p. 995 e 997. (grifo do livro); MARINONI, 2014. p. 1276-1277. 
xiste a possibilidade de revisão do voto, ou seja, estabelecida a posição do Estado votante, esta permanece, independente de decisão futura do Supremo Tribunal Federal, pois os órgãos da Organização das Nações Unidas encontram-se fora da jurisdição brasileira.

Poder-se-ia propor a Arguição para evitar lesão a preceito fundamental. No caso em análise, seria temerário, pois 1) trata-se de competência exclusiva do Chefe de Estado representar o Estado brasileiro no plano internacional e escolher as linhas de política exterior; logo, existe a barreira constitucional da independência dos Poderes (Art. $2^{\circ}$ da $\mathrm{CF}$ ); 2) segundo, o maior problema é que diante das relações internacionais e das particularidades das circunstâncias e dos valores que estão em jogo, qualquer predeterminação do órgão judiciário, no sentido de estabelecer previamente a posição que o Estado brasileiro deve adotar, coloca em risco, para dizer o mínimo, a violação de outros princípios das relações internacionais. Assim, o Poder Judiciário não pode atuar como administrador positivo ${ }^{52}$.

Dessa forma, é impossível prever as circunstâncias das negociações internacionais ao ponto de se exigir previamente do Chefe de Estado posições constitucionalmente aceitáveis. No caso em voga, as ponderações devem ser feitas pelo Chefe de Estado e seus acreditados ao representarem o Estado brasileiro no plano internacional, evitando que suas decisões sejam inconstitucionais. Diante desses argumentos, defende-se que a Arguição de descumprimento de preceito fundamental não seja apta a atacar ato violador da Constituição do Poder Público, Executivo da União, no plano internacional.

52 DIMOULIS, LUNARDI, 2011, p. 168. Ambos os argumentos servem para excluir, também, a ação civil pública (Art. 129, III, da CF) e a ação popular (Art. $5^{\circ}$, LXXIII, da CF). 


\section{Proposta de solução}

Como acima analisado, o ato do Chefe de Estado que violou princípio constitucional ao vincular o Estado brasileiro à decisão do Conselho de Direitos Humanos da Organização das Nações Unidas não responsabiliza o Presidente (Chefe de Estado) nem possui remédio constitucional para anulá-lo ou pô-lo em consonância com a norma constitucional. Assim, não é admissível em um Estado de Direito constitucional que ato político ou de governo se encontre na seara da inconstitucionalidade, sem que resulte em alguma consequência: anulação ou/e responsabilização. Destarte, identifica-se uma lacuna técnica ${ }^{53}$ no sistema jurídico brasileiro que pode ser colmatada com o preenchimento do legislador infraconstitucional no que se refere à regulamentação, da primeira parte, do inciso VII do Art. 85 da CF.

Defende-se que nos casos de relações internacionais do Estado brasileiro com outros órgãos internacionais, que não redundem em internalização de texto normativo, a forma mais adequada de se proteger a Constituição de violações é responsabilizar o Chefe de Estado por violá-la. Isso pela característica peculiar do tempo e do espaço onde o ato do Chefe de Estado se constitui e se exaure. Essas características não permitem que ações constitucionais atuem sobre $o$ ato inconstitucional. A responsabilização é a forma adequada em relação à arbitrariedade do representante do Estado brasileiro.

Nesse sentido, seria necessário chamar atenção do Legislador, inclusive com uma Ação Declaratória de Inconstitucionalidade por Omissão, para que o mesmo providencie a regulamentação da parte que tange ao cumprimento das leis,

53 GUASTINI, 2010, p. 333. 
completando a Lei n. 1.079/50. Com isso, a violação de texto constitucional entraria como tipo de crime de responsabilidade do Presidente da República. Por fim, ocorrendo essa regulamentação, dar-se-ia eficácia material ao Art. 78 da CF. Por conseguinte, exigir que o Presidente mantenha, defenda e cumpra a Constituição e observe as leis não é nada além do que o compromisso prestado pelo mesmo no momento do ato formal e solene da posse diante do Congresso Nacional.

\section{Conclusão}

O texto trata da problemática de ato político do Chefe de Estado que viola princípio constitucional em âmbito internacional. Com isso, a partir das características do Estado de Direito constitucional, é inapropriado sustentar e aceitar ato do Poder Público (do Estado) que viola regra ou princípio constitucional, e, até mesmo, legal. Quando isso ocorre, o sistema jurídico-constitucional prevê ações de inconstitucionalidade e remédios constitucionais a fim de desconstituir o ato inconstitucional. Contudo, também prevê tipos de crime de responsabilidade do Presidente da República.

Não obstante esses vários recursos para atacar o ato inconstitucional e responsabilizar o violador da constituição, o ato em análise possui características próprias, fugindo dos mecanismos de proteção constitucional. Seu tempo e espaço são excepcionais. Em relação ao tempo do ato político em voga, ele se exauriu no momento da votação no Conselho de Direitos Humanos, vinculando, de imediato, o Estado brasileiro à posição politicamente definida pelo mesmo. Nesse sentido até se poderia anular a declaração e a anulação se as circunstâncias permanecem em vigência. Como se trata de Proposta de Resolução, após a votação de todos os Estados 
membros do Conselho de Direitos Humanos, fica eternizada a declaração dos Estados em face da Proposta de Resolução, transformando-a em Resolução ou não.

No condizente ao espaço, trata-se de ato político realizado para além das fronteiras da jurisdição brasileira. Com isso, qualquer decisão judicial que se possa ter em relação ao fato em análise é inócua, pois a opção do veto pelo Estado brasileiro é legítima, estando de acordo com as normas que regem a Organização das Nações Unidas e, por conseguinte, o direito internacional. Soma-se a isso, o fato de que o único indivíduo legitimado e reconhecido a representar o Estado brasileiro, em termos de manifestação, é o Chefe de Estado (o Presidente da República), e não o Supremo Tribunal Federal ou o Presidente do Congresso Nacional.

Cabe destacar que, perante o cenário traçado na análise, é preciso evitar a violação de princípio constitucional das relações internacionais por parte do Chefe de Estado e seus acreditados. Anular por meio de inconstitucionalidade o ato, como visto, não é possível por suas características. Portanto, responsabilizar o Chefe de Estado por tal violação seria o mais adequado ao sistema brasileiro, justamente para evitar algo que perdurará no tempo como inconstitucionalidade.

\section{Referências bibliográficas}

ALMEIDA, Paulo Roberto de. As relações internacionais na ordem constitucional. In: Revista de Informação Legislativa. a. 26, n. 101, jan./mar. 1989. Brasília: Senado federal. p. 47-70.

ÁVILA, Humberto. Teoria dos princípios da definição à aplicação dos princípios jurídicos. 13 ed. São Paulo: Malheiros, 2012.

BARROSO, Luís Roberto. Crimes de responsabilidade e processo de impeachment. In: CLÈVE, Clèmerson Merlin; 
BARROSO, Luís Roberto. Direito constitucional: organização do Estado. São Paulo: Revista dos Tribunais, 2011. (Coleção doutrinas essenciais; v. 3). p. 615-631.

BRASIL. Supremo Tribunal Federal. A Constituição e o Supremo [recurso eletrônico]. 5 ed. Brasília: STF, Secretaria de Documentação, 2016.

BROSSARD, Paulo. O impeachment. Aspectos da responsabilidade política do Presidente da República. 3 ed. São Paulo: Saraiva, 1992.

CAMPANHOLE, Adriano; CAMPANHOLE, Hilton Lobo. Constituições do Brasil. 9. ed. São Paulo: Atlas, 1986

CANOTILHO, José Joaquim Gomes. Direito constitucional e teoria da constituição. 5 ed. Coimbra: Almedina, 2002.

CRETELLA JÚNIOR, José. Natureza jurídica do impeachment no Brasil. In: CLÈVE, Clèmerson Merlin; BARROSO, Luís Roberto. Direito constitucional: organização do Estado. São Paulo: Revista dos Tribunais, 2011. (Coleção doutrinas essenciais; v. 4). p. 497-510.

DIMOULIS, Dimitri; LUNARDI, Soraya. Curso de processo constitucional: controle de constitucionalidade e remédios constitucionais. São Paulo: Atlas, 2011.

FIGUEIREDO, Paulo de. Impeachment sua necessidade no regime presidencial. In: Revista de Informação Legislativa. Junho. 1965. Brasília: Senado federal. p. 31-46.

GALINDO, George Rodrigo Bandeira. Comentário ao artigo 84, VII. In: CANOTILHO, J.J. Gomes; MENDES, Gilmar F.; SARLET, Ingo W.; STRECK, Lenio L. (Coords.). Comentários à Constituição do Brasil. São Paulo: Saraiva: Almedina, 2013. p. 1238-1241.

GUASTINI, Ricardo. Le fonti del diritto. Fundamenti teorici. Milano: Giuffrè, 2010. 
HESSE, Konrad. Grundzüge des Verfassungsrechts der Bundesrepublick Deutschland. 19 Aufl. Heidelberg: Müller, 1993.

KRIELE, Martin. Einführung in die Staatslehre. 4.Aufl. Opladen: Westdeutscher Verlag, 1990.

LARENZ, Karl. Derecho justo. Fundamentos de etica juridica. Trad. Luis Díez-Picazo. Madrid: Civitas, 2001.

LOMBA, Pedro. Teoria da responsabilidade política. Coimbra: Coimbra, 2008.

MASSAÚ, Guilherme. A função dos princípios fundamentais do Art. $4^{\circ}$ da Constituição Federal de 1988. Monografia de Estágio Pós-Doutoral, com o Prof. Dr. Ingo Wolfgang Sarlet, na Pontifícia Universidade Católica do Rio Grande do Sul, 2017.

MELLO, Celso Antônio Bandeira. Curso de direito administrativo. 13 ed. São Paulo: Malheiros, 2001.

PONTES DE MIRANDA, Francisco Cavalcanti. Questões forenses. t. V. Rio de Janeiro: Borsoi, 1959.

SARLET, Ingo Wolfgang, MARINONI, Luiz Guilherme e MITIDIERO, Daniel. Curso de direito constitucional. 3 ed. São Paulo: Revista dos Tribunais, 2014.

SILVA, José Afonso da. Comentário contextual à constituição. 7 ed. São Paulo: Malheiros, 2010.

SIQUEIRA JR., Paulo Hamilton. Direito processual constitucional. 5 ed. São Paulo: Saraiva, 2011.

STRECK, Lenio Luiz; OLIVEIRA, Marcelo Andrade Cattoni de; BAHIA, Alexandre. Comentário ao artigo 85. In: CANOTILHO, J.J. Gomes; MENDES, Gilmar F.; SARLET, Ingo W.; (Coords.). Comentários à Constituição do Brasil. São Paulo: Saraiva: Almedina, 2013. p. 1285-1287.

TAVARES, Iris Eliete Teixeira Neves de Pinho. O presidente da república no sistema presidencialista brasileiro. In: Revista 
de Informação Legislativa. a. 33, n. 130, abril/jun. 1996. Brasília: Senado federal. p. 165-173.

UZIEL, Eduardo, MORAES, Henrique Choer e RICHE, Flavio Elias. Entre direito e política externa - elementos para a interpretação do Art. $4^{\circ}$ da Constituição. In: Revista de Direito Constitucional e Internacional. a. 25, v. 99, jan.-fev. 2017, São Paulo: RT. p. 95-120.

ZIPPELIUS, Reinhold. Allgemeine Staatslehre. 12 Aufl. München: Beck, 1994.

Recebido em 07/10/2017.

Aprovado em 23/04/2018.

Guilherme Camargo Massaú

E-mail: uassam@gmail.com 